\title{
The effect of level of dietary calcium and phosphorus on skeletal development in the young pig to $25 \mathrm{lb}$ live weight
}

\author{
BY R. BLAIR* AND D. BENZIE \\ Rowett Research Institute, Bucksburn, Aberdeen \\ (Received 9 May 1963-Accepted 22 fuly 1963)
}

In this series of papers the first (Blair, 1963) described synthetic diets for young pigs, and the second (Blair, Diack \& McPherson, 1963) described the pattern of development of the limb bones of suckled pigs during the first 8 weeks of life.

The aim of the study now described was to determine what dietary levels of calcium and phosphorus, with or without the addition of fresh ox liver, would promote satisfactory bone development in piglets weaned from the sow at about Io days of age. The criteria used to assess bone development were: the width of the distal epiphysial cartilage of the ulna; the relationship between epiphysial size and live weight; the weight of the dry fat-free skeleton and the amount and composition of the ash; and bone density measured radiographically.

\section{EX PERI MENT A L}

Diets. The basal portion of the diets described by Blair ( $\left.196_{3}\right)$ was composed of casein 30 , maize starch 15 , glucose 30 , sucrose 10 , lard 5 , vitamin supplement 1 , tracemineral supplement $\mathrm{I}$, potassium supplement $\mathrm{I}$ and sodium chloride $0.5 \%$, and antibiotics. It contained $0.00 \% \mathrm{Ca}$ and $0.24 \% \mathrm{P}$. Four different levels of $\mathrm{Ca}$ and $\mathrm{P}$ were compared and these were obtained by varying the proportions of sucrose and $\mathrm{CaHPO}_{4}$ added as a $\mathrm{Ca}$ and $\mathrm{P}$ supplement. Fresh ox liver was added to half of the diets. These additions and resulting levels of $\mathrm{Ca}$ and $\mathrm{P}$ are shown in Table $\mathrm{I}$.

Table I. Additions to basal diet $(93.5 \mathrm{lb})$ and resulting levels of calcium and phosphorus

\begin{tabular}{|c|c|c|c|c|c|}
\hline \multirow[b]{2}{*}{$\begin{array}{l}\text { Diet } \\
\text { no. }\end{array}$} & \multirow[b]{2}{*}{$\underset{\text { (g) }}{\text { Sucrose }}$} & \multirow[b]{2}{*}{$\underset{(\mathrm{g})}{\mathrm{CaHPO}}$} & \multirow[b]{2}{*}{$\begin{array}{l}\text { Fresh ox } \\
\text { liver }\end{array}$} & $\mathrm{Ca}$ & $P$ \\
\hline & & & & \multicolumn{2}{|c|}{$\begin{array}{l}\text { (percentage in } \\
\text { air-dry diet) }\end{array}$} \\
\hline I & 2311 & 640 & - & 0.4 & 0.6 \\
\hline 5 & 2311 & 640 & + & 0.4 & 0.6 \\
\hline 2 & 1671 & 1280 & - & 0.8 & 0.9 \\
\hline 6 & 1671 & I 280 & + & 0.8 & 0.9 \\
\hline 3 & $103 \mathrm{I}$ & 1920 & - & $\mathrm{I} \cdot \mathbf{2}$ & $\mathrm{I} \cdot \mathbf{2}$ \\
\hline 7 & $103 \mathrm{I}$ & 1920 & + & $\mathrm{I} \cdot 2$ & $\mathrm{I} \cdot \mathbf{2}$ \\
\hline 4 & 391 & 2560 & - & $1 \cdot 6$ & $1 \cdot 5$ \\
\hline 8 & 391 & 2560 & + & $x \cdot 6$ & 1.5 \\
\hline
\end{tabular}

- Present address: Department of Agriculture, University of Aberdeen. 
It was expected that these levels of $\mathrm{Ca}$ and $\mathrm{P}$ would provide a range both above and below the pigs' requirement, on the assumption that skeletal growth is satisfactory on sow's milk, which contains about $\mathrm{r} \% \mathrm{Ca}$ and $0.7 \% \mathrm{P}$ in the dry matter.

The piglets receiving fresh minced ox liver were given the daily allowances of $20 \mathrm{~g}$ for the first 2 weeks, $3 \circ \mathrm{g}$ during the $3^{\text {rd }}$ week and $4 \circ \mathrm{g}$ during the $4^{\text {th }}$ and $5^{\text {th }}$ weeks.

Animals. Four litters of eight piglets were used to test the eight treatments; each litter represented a complete replicate of the experiment, which was of a $4 \times 2$ factorial design. 'The litters were out of Wessex Saddleback sows by either a Large White or Landrace boar. The piglets were taken from the sow when their mean weight was about $8 \mathrm{lb}$, ear-marked and the males castrated. They were then allocated to the experimental treatment according to a randomized plan, sex being disregarded.

The management of the animals was similar to that described by Blair ( 1963$)$.

On reaching $25 \mathrm{lb}$ live weight each piglet was anaesthetized and killed by bleeding. Removal and preparation of the skeleton was as described by Blair et al. (1963).

Radiographs. Radiographs were taken of the fore and hind limbs at weaning and once each week after a weighing. The operative voltage was progressively raised from $62 \mathrm{kV}$ at weaning to $68 \mathrm{kV}$ at $25 \mathrm{lb}$ live weight; otherwise the radiographic ratings were kept constant at $100 \mathrm{~mA}$, exposure $0.12 \mathrm{sec}$ and tube focus-film distance 36 in. From the radiographs obtained, measurements were made of the width of the distal epiphysial cartilage of the ulna, of the length and breadth of the distal epiphysis of the ulna, and of the length and breadth of the proximal epiphysis of the tibia, by the method described previously (Blair et al. 1963).

After slaughter, radiographs were also made, in the dry flesh-free state, of the mandible, cervical vertebras 1,3 and 5 , thoracic vertebras $1,5,8$, 12 and $1_{5}$, lumbar vertebras $I, 3$ and 5 , sacrum, radius, humerus and femur. Radiographic ratings were again kept constant at $68 \mathrm{kV}, 100 \mathrm{~mA}$, exposure $0^{\circ} \mathrm{I} \mathrm{sec}$, and tube focus-film distance $3^{6}$ in.

Bone density. Radiographic density of the selected bones was assessed as outlined in a previous report (Blair et al. 1963 ). The assessed values were then expressed as a percentage of an optimum value to give percentage density.

Bone analysis. The mandible, cervical vertebras $I, 3$ and 5 , thoracic vertebras I, 5 , 8,12 and 15 , lumbar vertebras 1,3 and 5 , the first two ribs and the last two ribs from one side, all the ribs from the other side, the sacrum, radius, humerus, femur, the total fore limb, total hind limb and the remainder of the skeleton were analysed for ash content and ash composition by the methods described by Blair et al. (1963).

Statistical methods. The results were analysed by the conventional techniques of analysis of variance and regression analysis.

\section{RESUL'TS}

Health. Three piglets died, two from big-liver disease (Shanks, 1953) with associated gut oedema in one of them, and one from necrotic enteritis. There was some scouring which was quickly cured by treatment (Blair, 1963 ). Incidence of scouring was unaffected by the levels of $\mathrm{Ca}$ and $\mathrm{P}$ in the dict. 
Supplementation of the diet with fresh minced ox liver significantly improved the appearance of the piglets. Those receiving liver had a smooth pinkish skin and were less hairy than those not receiving liver.

At $25 \mathrm{lb}$ live weight the piglets were examined clinically for the presence or absence of limb deformities. All of the pigs from one litter showed slight leg weakness, as did four others in whom the incidence could not be attributed to any one treatment.

Growth performance of the piglets. The level of $\mathrm{Ca}$ and $\mathrm{P}$ in the diet had no significant effect on the rate of weight gain or food conversion efficiency (Table 2).

Table 2. Effect of level of dietary calcium and phosphorus and of added ox liver on mean growth performance of the piglets (mean values with their standard errors for eight groups of four piglets)

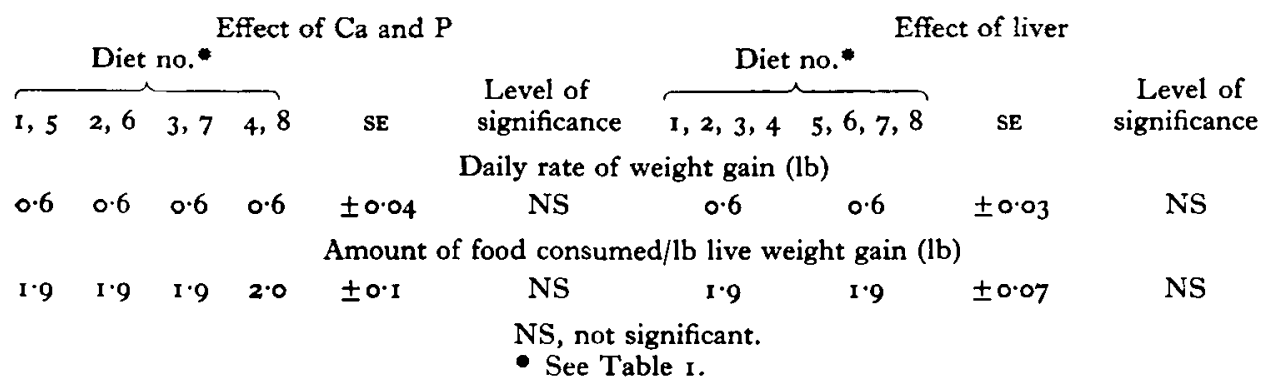

Skeletal growth. Bone development was assessed at two stages, after the end of 3 weeks on experiment and at $25 \mathrm{lb}$ live weight. The effect of raising the level of $\mathrm{Ca}$ and $\mathrm{P}$ in the diet (Table 3, Pl. I) was to reduce significantly the width of epiphysial cartilage at both stages $(P<0.00 \mathrm{I})$. At about $25 \mathrm{lb}$ live weight supplementation of the diet with liver had a significant effect in reducing cartilage width $(P<0.01)$, but only at the lower levels of $\mathrm{Ca}$ and $\mathrm{P}$. This interaction between $\mathrm{Ca}$ and $\mathrm{P}$ level and liver was significant at $P<0.05$. Supplementation of the diet with liver had no significant effect on cartilage width after 3 weeks on experiment.

Raising the level of $\mathrm{Ca}$ and $\mathrm{P}$ in the diet had no significant effect on length or breadth of the ulnar or tibial epiphysis at the end of 3 weeks on experiment or at $25 \mathrm{lb}$ live weight (Table 3 ), or on the regression of epiphysial size on $\log _{10}$ live weight (Blair et al. 1963). There were highly significant differences in epiphysial size between litters, but they did not affect epiphysial size at fixed age (after 3 weeks on experiment) or the slope of the regression curve.

Weight, ash content and ash composition of the skeleton. Raising the level of $\mathrm{Ca}$ and $\mathrm{P}$ in the diet led to a significant increase in the dry fat-free weight $(P<0.01$ or $P<0.001)$ and ash content $(P<0.001)$ of the bones and whole skeleton, as shown in Tables 4 and 5 .

Supplementing the diet with liver led to a reduction in the ash content of the first and last two ribs from one side $(P<0.05)$, but this result is not regarded as having any great significance.

Raising the level of $\mathrm{Ca}$ and $\mathrm{P}$ in the diet affected the ash composition of only two parts of the skeleton (Table 6): the content of $\mathrm{Ca}$ in the ash of the sacrum was higher 
on the diets with the lowest level of $\mathrm{Ca}$ and $\mathrm{P}$ than on the others $(P<0.0 \mathrm{I})$, and the content of $P$ in the ash of the lumbar vertebras increased with increasing level of $\mathrm{Ca}$ and $P$ in the diet $\left(P<0^{\circ} 01\right)$. There were significant differences between litters in the Ca content of the ash for all parts of the skeleton, but in the $P$ content of the ash only for the lumbar vertebras and the first and last ribs. Again, these results are not regarded as having any great significance.

Table 3. Effect of level of dietary calcium and phosphorus and of added ox liver on length and breadth $(\mathrm{cm})$ of the distal epiphysis of the ulna and proximal epiphysis of the tibia and on width (cm) of distal epiphysial cartilage of the ulna of the piglets (mean values with their standard errors for eight groups of four piglets)

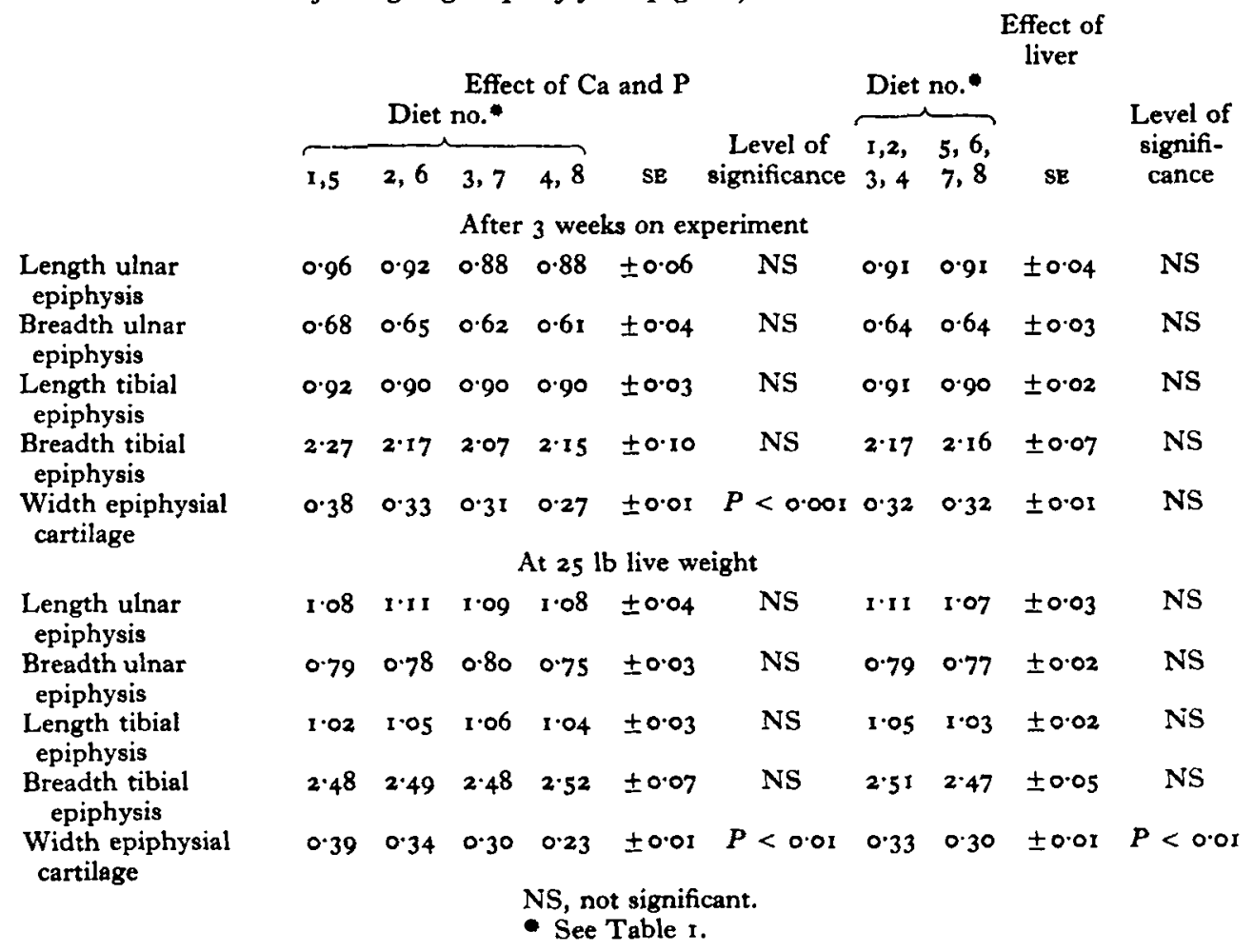

Bone density. Table 7 shows that the radiographic density of each part of the skeleton increased significantly $(P<0.001)$ as the level of $\mathrm{Ca}$ and $\mathrm{P}$ in the diet was increased. Pl. 2 shows the effect on the radiographic density of the mandible. Supplementation of the diet with liver increased the density of all the bones with the exception of the vertebras. There were significant differences between litters in the density of some parts of the skeleton, and for the cervical vertebras there was a significant interaction $(P<0.0 \mathrm{I})$ between the presence of liver in the diet and $\mathrm{Ca}$ and $\mathrm{P}$ level, whereby density was higher at the lower levels of $\mathrm{Ca}$ and $\mathrm{P}$ but only when liver was given. 
Table 4. Effect of level of dietary calcium and phosphorus and of added ox liver on the dry fat-free weight $(g)$ of the skeletons of the piglets (mean values with their standard errors for eight groups of four piglets)

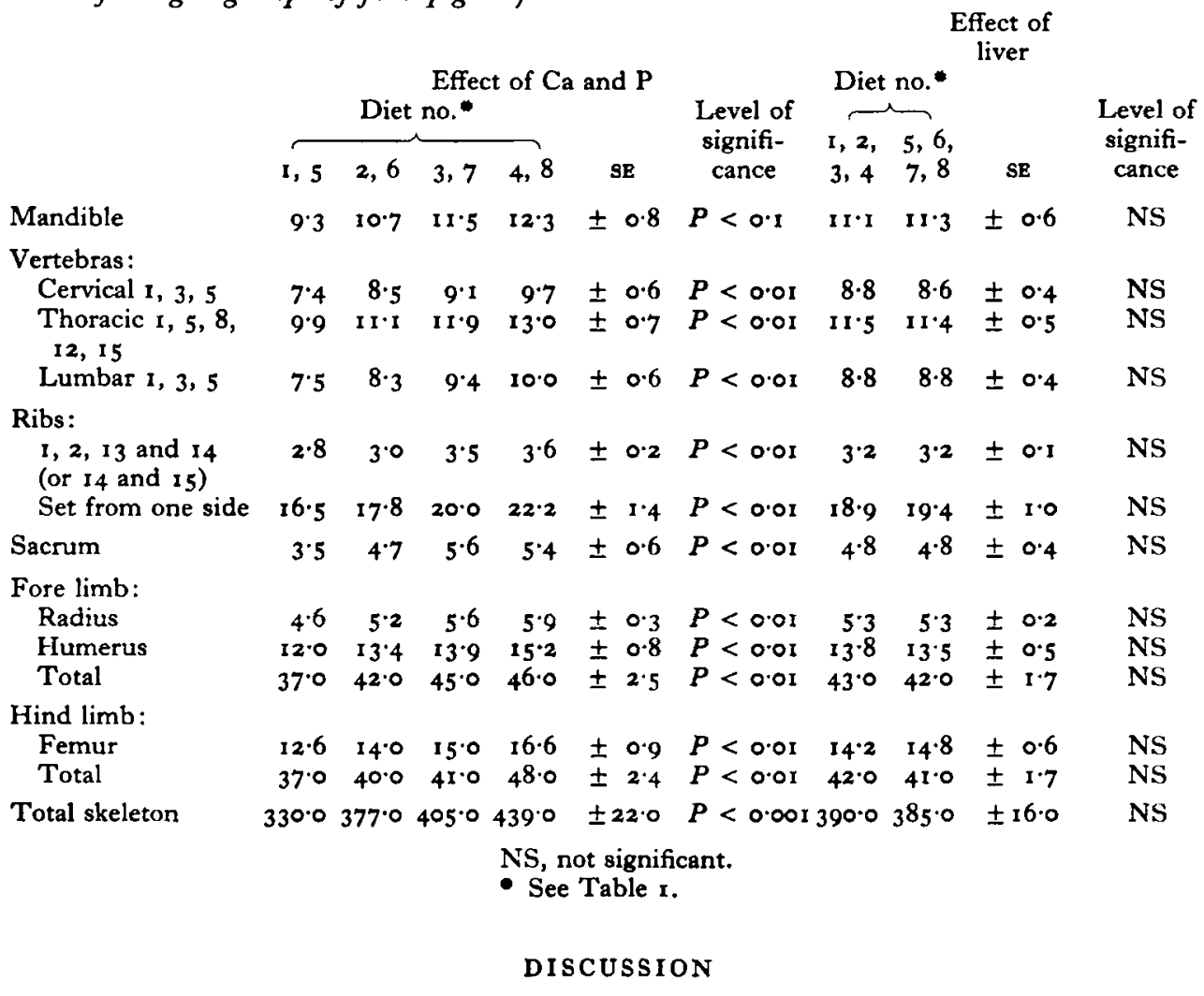

Increasing the dietary levels of $\mathrm{Ca}$ and $\mathrm{P}$ from 0.4 and $0.6 \%$ to $\mathrm{I} \cdot 6$ and $\mathrm{I} \cdot 5 \%$, respectively, had no significant effect on the rate at which the piglets gained weight, a result similar to that obtained by Rutledge (1957). The relationship between epiphysial size and live weight was found to be the same as that established previously for suckled piglets (Blair et al. 1963), although it might have been expected that growth in the size of the epiphyses would be slower in mineral-deficient piglets. Therefore it was not possible to use either rate of gain in weight or size of the epiphyses in relation to live weight as a criterion in assessing bone growth in the young pigs.

However, the width of the distal epiphysial cartilage of the ulna was significantly affected by the level of $\mathrm{Ca}$ and $\mathrm{P}$ in the diet. Rickets is characterized by changes associated with defective calcification of the bones. Throughout the growth period bone is constantly broken down and remodelled. The result of a deficiency of boneforming materials is failure of new bone tissue to ossify, and in the epiphysial regions, namely, the provisional zones of calcification, there is lack of deposition of mineral salts and consequent persistence of cartilage (Harris, 1933; Brailsford, 1948; Weinmann \& Sicher, 1955). On the diets containing 0.4 and $0.8 \% \mathrm{Ca}$ and 0.6 and $0.9 \% \mathrm{P}$ there was widening of the epiphysial cartilage. Closure which was satisfactory in 
Table 5. Effect of level of dietary calcium and phosphorus and of added ox liver on the ash content $(\%)$ of the dry fat-free skeletons of the piglets (mean values with their standard errors for eight groups of four piglets)

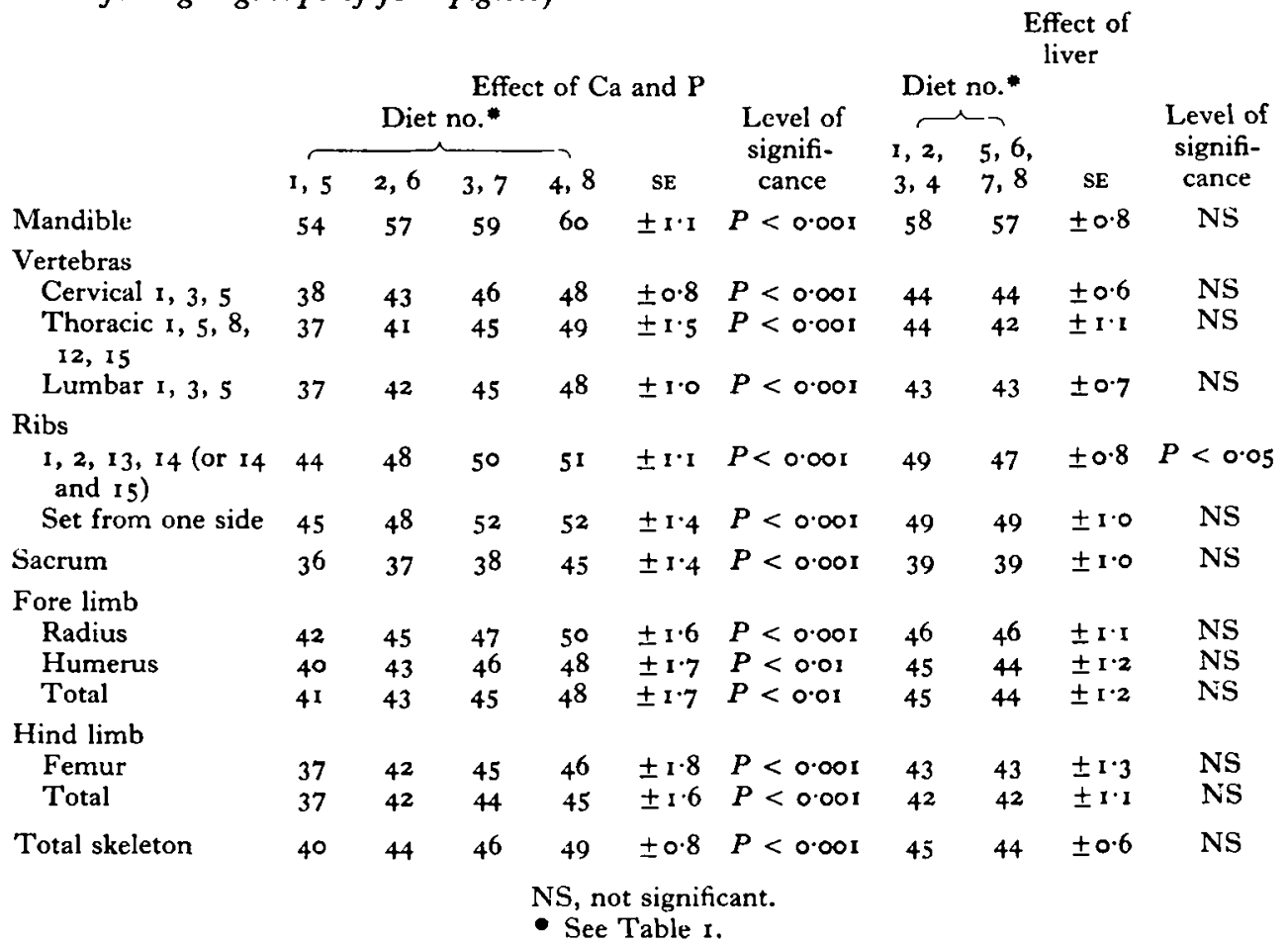

relation to that obtained in suckled piglets (Blair et al. 1963) took place on the diet containing $1.6 \% \mathrm{Ca}$ and $\mathrm{I} \cdot 5 \% \mathrm{P}$, although there was some closure on the diet containing $\mathrm{I} \cdot 2 \% \mathrm{Ca}$ and $\mathrm{I} \cdot 2 \% \mathrm{P}$. Therefore it would appear that piglets given the diets containing the lower levels of $\mathrm{Ca}$ and $\mathrm{P}$ had rickets, but as there were no associated limb deformities the condition should perhaps be correctly termed subclinical rickets.

Since increasing the $\mathrm{Ca}$ and $\mathrm{P}$ content of the diet led to more rapid closure of the epiphysial cartilage it was considered that skeletal growth was best on the diets containing the highest levels of $\mathrm{Ca}$ and $\mathrm{P}$. The epiphysial cartilage, at $25 \mathrm{lb}$ live weight, was very slightly wider $(0.23 \mathrm{~cm})$ in piglets given the highest levels of $\mathrm{Ca}$ and $\mathrm{P}$ than in suckled piglets $(0 \cdot 20 \mathrm{~cm})$ (Blair et al. 1963$)$, although the growth check at weaning may have caused a retardation in skeletal growth. It is possible therefore that still higher dietary levels of $\mathrm{Ca}$ and $\mathrm{P}$ might have further decreased the width of epiphysial cartilage. Dry fat-free weight, ash content and density of the skeleton were also increased by raising the intake of $\mathrm{Ca}$ and $\mathrm{P}$, which might indicate also that skeletal development was most rapid on the diets containing the highest levels of $\mathrm{Ca}$ and $\mathrm{P}$.

Supplementation of the diet with liver had a beneficial effect on the appearance of the piglets but did not affect either their rate of gain in weight or their food conversion efficiency. The width of the distal epiphysial cartilage of the ulna on the lower $\mathrm{Ca}$ and 


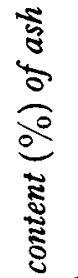

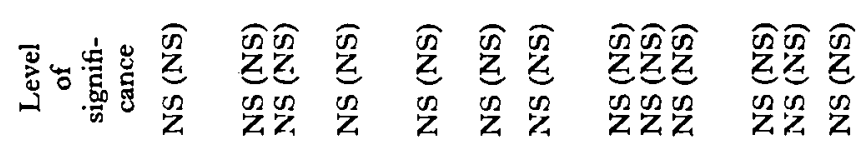

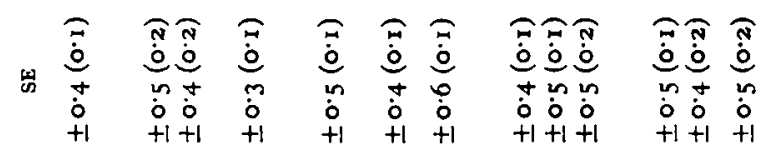

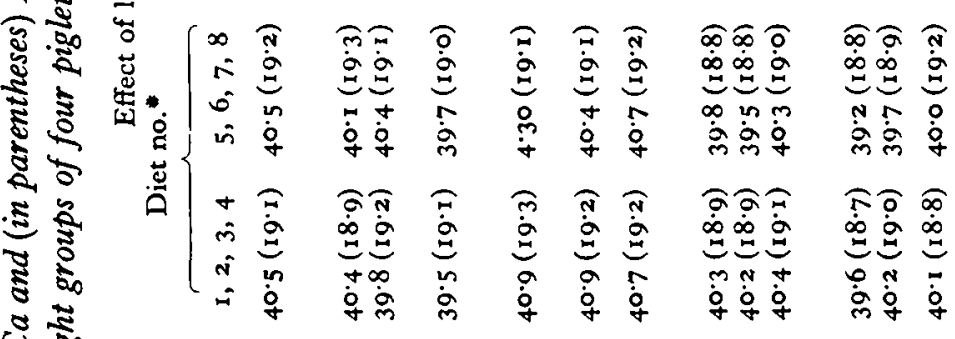

0.

:

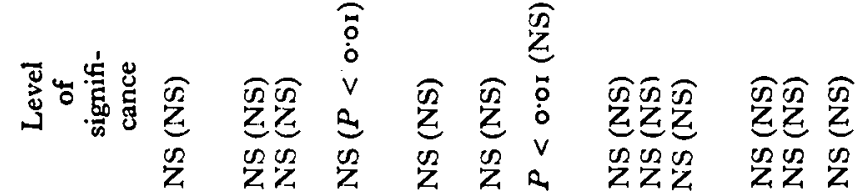

:

४ै

䍜旁

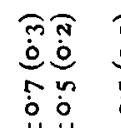

8

है

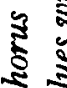

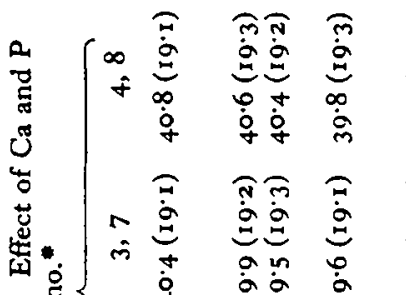

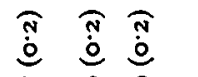

१ํา

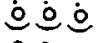

ํ.

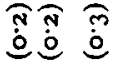

个o

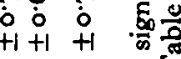

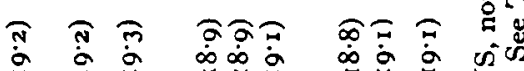

०

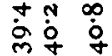

क

है

s

हैำ

(2)

के के

(2)

웧ำ

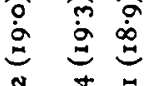

ลิธ กิ

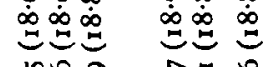

no

峁

ํํำ 음

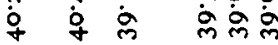

बें

है $\frac{8}{5}$

(i) $\Xi \pm \Xi$

कि

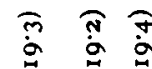

ำ

ลิำ

a

$\pm=$

$\dot{\infty} \equiv$

के

:

bั5

密 $\frac{1}{\pi}$

के

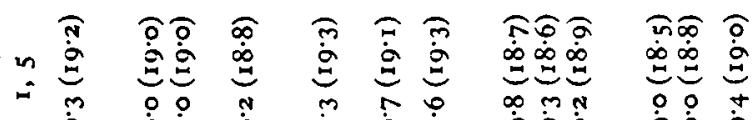

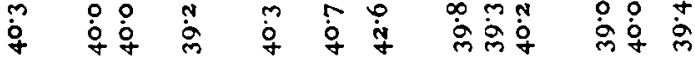

芯

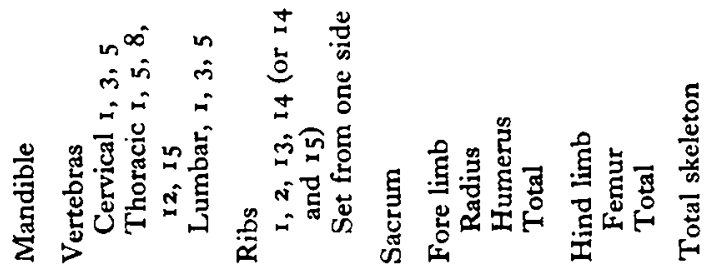


Table 7. Effect of level of dietary calcium and phosphorus and of added ox liver on the radiographic density $(\%)$ of the dry fat-free skeletons of the piglets (mean values with their standard errors for eight groups of four piglets)

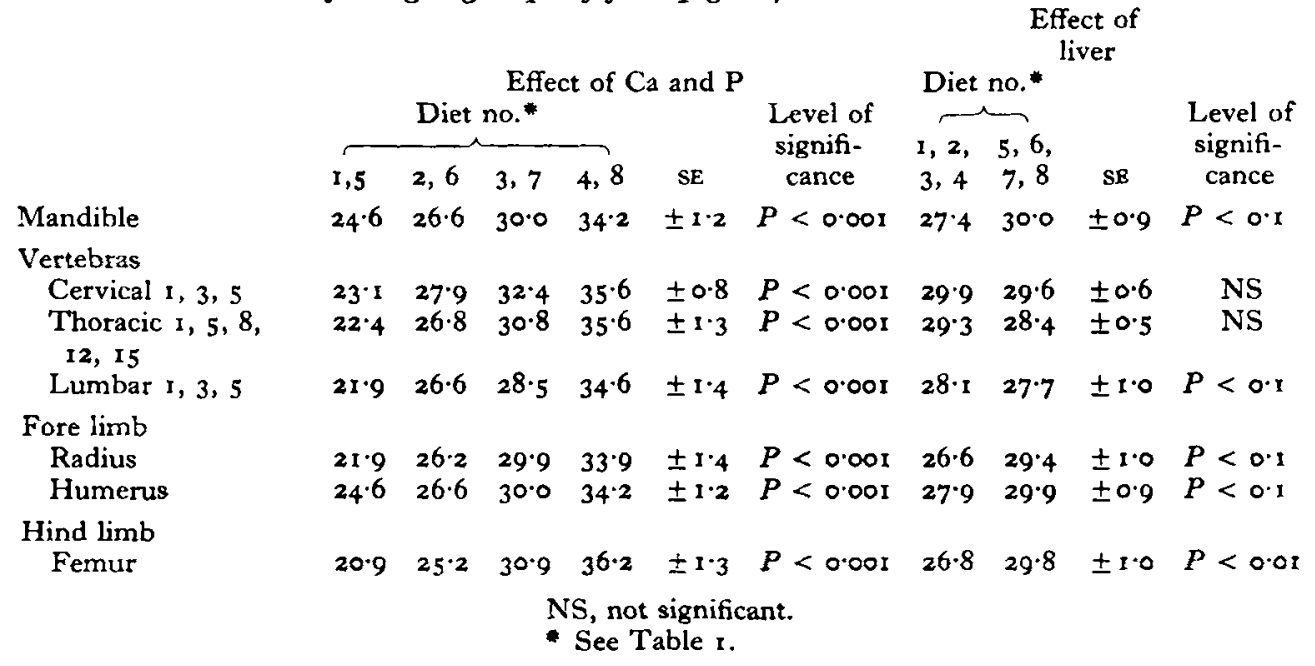

$P$ levels and bone density were influenced by liver supplementation, although calcification of the skeleton was otherwise unaffected. The effect on bone development cannot be attributed to the amount of $\mathrm{Ca}$ and $\mathrm{P}$ provided by the liver since, by analysis, it contained only $0.1 \mathrm{I} \% \mathrm{Ca}$ and $0.25 \% \mathrm{P}$ in the dry matter, and it can only be concluded that ox liver contains a factor able to influence calcification and the appearance of the skin of piglets given the particular synthetic diets used, perhaps through promotion of better health in general and haematopoiesis in particular.

The drinking water given to the piglets contained some $\mathrm{Ca}$ and $\mathrm{P}$ since it was derived from the mains supply, but on the basis of average analyses of the water supply by the Public Analyst and of water intake figures obtained by Livingstone, Lucas \& McDonald (1962) the mean total intake of Ca from that source was only $250 \mathrm{mg}$ and the mean total intake of $\mathrm{P} 2 \mathrm{mg}$ over the whole experimental period.

The dry matter of sow's milk contains about $\mathrm{x} \% \mathrm{Ca}$ (Hughes \& Hart, 1935; Braude, Coates, Henry, Kon, Rowland, Thompson \& Walker, r947; Perrin, 1955) which Freese (1958) has found to be about $95 \%$ retained; this high percentage retention is perhaps a result of the presence of lactose (Lengemann, Wasserman \& Comar, 1959). On this basis the available Ca content of the dry matter in sow's milk is therefore $0.95 \%$. Since a level of $\mathrm{Ca}$ in a synthetic diet higher than that found in the dry matter of sow's milk has been shown to be inadequate for optimum skeletal development, it follows that the $\mathrm{Ca}$ supplied by the synthetic diet must have been of lower availability, since intakes of synthetic diet and sow's-milk dry matter appear to have been about equal (Blair, r 963 ; Blair et al. 1963). Results of digestibility studies carried out by Livingstone et al. (1962) confirm that Ca supplied as $\mathrm{CaHPO}_{4}$ is of lower availability than the $\mathrm{Ca}$ of sow's milk, being about $73 \%$ retained when it forms $\mathrm{x} \cdot 6 \%$ of the diet. 
This experiment suggested that skeletal development was most rapid when the diet contained $\mathrm{r} \cdot 6 \% \mathrm{Ca}$. It would appear that for satisfactory skeletal development the available $\mathrm{Ca}$ content of the dietary dry matter should be at least $\mathrm{I} \cdot 3 \%$ when the diet contains $\mathrm{I} \cdot 5 \% \mathrm{P}$ and $\mathrm{I} 5 \mathrm{O}$ i.u. vitamin $\mathrm{D} / \mathrm{lb}$. Higher levels of $\mathrm{Ca}$ may be necessary for optimum skeletal development.

This estimate of $\mathrm{Ca}$ requirement is higher than estimates suggested by most other workers, although Freese (1958) recommended that sow's-milk substitutes should contain $1.3 \% \mathrm{Ca}$ in readily available form. Rutledge (1957) and Rutledge, Hanson \& Meade (I96I) gave diets containing $0.4,0.6,0.8$ and $\mathrm{I} \% \mathrm{Ca}$ (mainly in the form of limestone) and $0.6 \% \mathrm{P}$ to pigs over the age period from 3 to 9 weeks. During this relatively long experimental period nutrient requirements would undoubtedly change, but $0.8 \% \mathrm{Ca}$ was suggested as a minimum requirement on the basis of the ash and $\mathrm{Ca}$ contents and the density of the femur and the breaking strength and radiographic density of the humerus. No details of the availability of the $\mathrm{Ca}$ were given, and, since the breaking strength $(P<0.001)$, the ash and $\mathrm{Ca}$ contents $(P<0.01)$ and the density of the bones $(P<0.001)$ were significantly increased with increase in dietary Ca level from 0.4 to $\mathrm{I} \%$, the requirement for maximum rate of bone calcification would appear to be at least $1 \%$. The (USA) National Research Council (1959) give the $\mathrm{Ca}$ requirement of the $10 \mathrm{lb}$ pig as $0.7 \%$ of the dry matter but they do not state how this figure was derived. Dudley, Becker, Norton \& Jensen ( 1961 ) studied the response of young pigs to dietary $\mathrm{Ca}$ (mostly from $\mathrm{CaCO}_{3}$ ) levels ranging from 0.1 to $2 \%$. It was found that $0.2 \% \mathrm{Ca}$ supported maximum rate of weight gain and maximum efficiency of food conversion, but the ash content of the femur increased with all increments of $\mathrm{Ca}$ up to $2 \%$ of the diet.

The $\mathrm{Ca}: \mathrm{P}$ ratio of the $\mathrm{CaHPO}_{4}$ given as the dietary source of $\mathrm{Ca}$ and $\mathrm{P}$ in our experiment was about $1 \cdot 25: 1$. Livingstone et al. (1962), however, have found that $\mathrm{Ca}$ and $\mathrm{P}$ from these synthetic diets were retained in the ratio of $\mathrm{I} \cdot \mathrm{I}: \mathrm{I}$. The $\mathrm{P}$ requirement is therefore probably less than the $\mathrm{Ca}$ requirement, but will depend on the level of $\mathrm{Ca}$ and vitamin $\mathrm{D}$ in the diet and on the relative availability of the minerals. Owing to the nature of our experiment it is not possible to give a precise estimate of $\mathbf{P}$ requirement, but a requirement of about $1-1 \cdot 2 \%$ available $P$ in the dietary dry matter is suggested. This estimate is again higher than that suggested by other workers, but few experiments have included $P$ in excess of $1 \%$ of the diet.

Freese's (1958) recommended allowance was $\mathrm{I} \cdot \mathrm{I} \% \mathrm{P}$ in a diet from which $73 \%$ of the $\mathrm{P}$ was retained. The (USA) National Research Council (1959) give the $\mathrm{P}$ requirement of the $10 \mathrm{lb}$ pig as $0.6 \%$ but again do not state how the estimate of $P$ requirement was derived. Vandepopuliere, Combs, Wallace \& Koger (1959) found that increasing the $P$ content of diets given to pigs weaned at 2 weeks from 0.2 to $0.7 \%$ caused an increase in bone density and ash content. Miller, Ullrey, Zutaut, Baltzer, Schmidt, Hoefer \& Luecke (196I) and Zimmerman, Speer \& Hays (196I) gave diets containing $0.2-0.8 \% \mathrm{P}$ to young pigs and again found an increase in ash content, breaking strength and radiographic density of the bones with increasing $P$ level. Combs, Vandepopuliere, Wallace \& Koger (1962) studied the P requirement of piglets from 2 to 7 weeks. Diets containing $0.24-0.72 \% \mathrm{P}$ and with different $\mathrm{Ca}: \mathrm{P}$ ratios 
were used and, although rate of weight gain was rather slow, bone ash and radiographic density values suggested a $\mathrm{P}$ requirement of $0.48 \%$ and a $\mathrm{Ca}: \mathrm{P}$ ratio of $0.9: \mathrm{I}$. None of these workers stated the availability of the dietary $\mathrm{P}$ but it is probable that their results indicate a requirement at least as high as that suggested by Freese's (1958) work.

\section{SUMMARY}

I. Synthetic diets formulated to provide adequate amounts of the known nutrients and containing $0.4,0.8,1 \cdot 2$ and $\mathrm{I} \cdot 6 \%$ calcium and $0.6,0.9, \mathrm{I} \cdot 2$ and $\mathrm{I} \cdot 5 \%$ phosphorus were given, with or without a supplement of fresh ox liver, to pigs of 8-25 lb live weight, according to a $4 \times 2$ factorial design involving four litters of eight piglets.

2. Radiographs were taken of the fore and hind limbs at the beginning of the experiment and once each week after a weighing in order to study bone development; after slaughter the mineralization of the skeletons was studied by chemical analysis and by radiography.

3. Supplementing the diet with fresh ox liver daily caused a significant improvement in the appearance of the pigs, but did not affect the rate of weight gain or the food conversion efficiency.

4. The levels of $\mathrm{Ca}$ and $\mathrm{P}$ in the diet had no significant effect on the rate of weight gain or the food conversion efficiency.

5. Raising the levels of $\mathrm{Ca}$ and $\mathrm{P}$ in the diet caused a significant increase in the dry fat-free weight, ash content, and radiographic density of each bone or group of bones studied but had little effect on their ash composition.

6. Width of distal epiphysial cartilage of the ulna was significantly decreased by raising the levels of $\mathrm{Ca}$ and $\mathrm{P}$ in the $\operatorname{diet}(P<0.001)$. There was an interaction $(P<0.05)$ whereby liver significantly reduced the width of cartilage $(P<0.01)$, but only at the two lower levels of $\mathrm{Ca}$ and $\mathrm{P}$.

7. Raising the levels of $\mathrm{Ca}$ and $\mathrm{P}$ in the diet had no significant effect on the size of the distal epiphysis of the ulna or proximal epiphysis of the tibia or on the slope of the regression of the length or breadth of the epiphysis on $\log _{10}$ live weight.

8. On the basis of the experimental findings and from results obtained by other workers a requirement for the $8-25 \mathrm{lb}$ pig of at least $1 \cdot 3 \%$ available $\mathrm{Ca}$ and a value somewhat less for $\mathbf{P}$ requirement are suggested.

We thank Professor I. A. M. Lucas for help in planning this work and in the preparation of the paper; Mr J. A. Crichton for help in the presentation of the results; Mr I. McDonald for the statistical analysis of the results; Mrs S. J. McPherson, Miss Irene Thomson, Messrs R. M. Livingstone and R. M. McPherson, and temporary members of staff for technical assistance; and Mr I. Philip for help in the care of the animals.

\section{REFERENCES}

Blair, R. (1963). Brit. F. Nutr. 17, I.

Blair, R., Diack, J. R. B. \& McPherson, R. M. (I963). Brit. F. Nutr. I7, 19.

Brailsford, J. F. (1948). The Radiology of Bones and Foints. London: J. and A. Churchill Ltd.

Braude, R., Coates, M. E., Henry, K. M., Kon, S. K., Rowland, S. J., Thompson, S.Y. \& Walker, D. M. (1947). Brit. F. Nutr. I, 64. 
British Fournal of Nutrition, Vol. I 8, No. I

Plate I
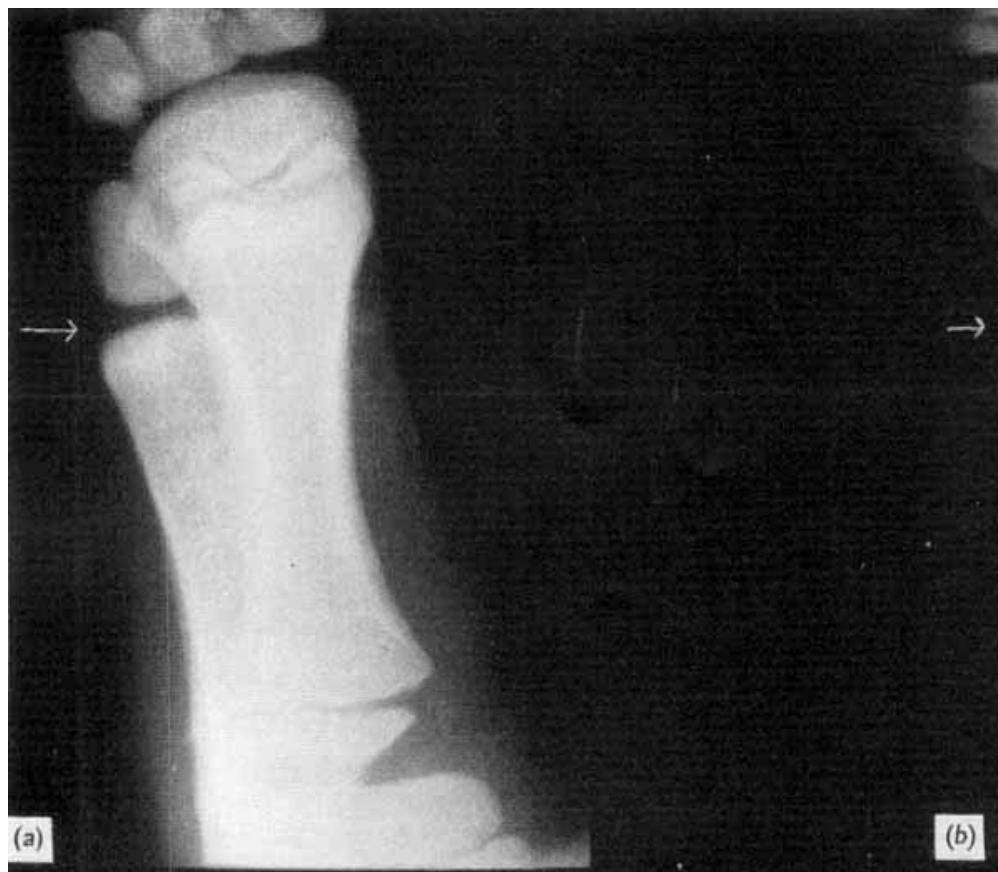

$\rightarrow$

(b)
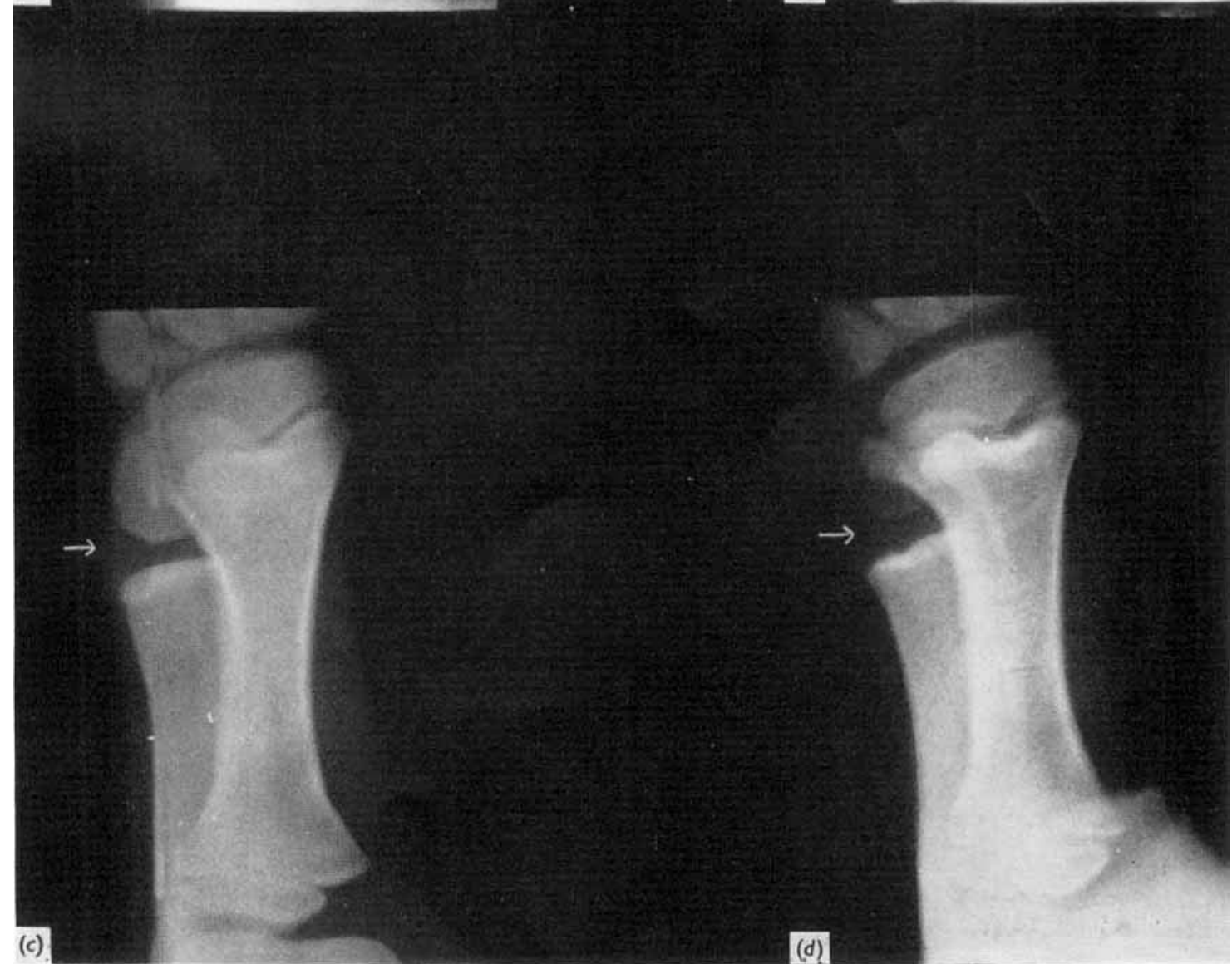

R. BLAIR AND D. BENZIE 


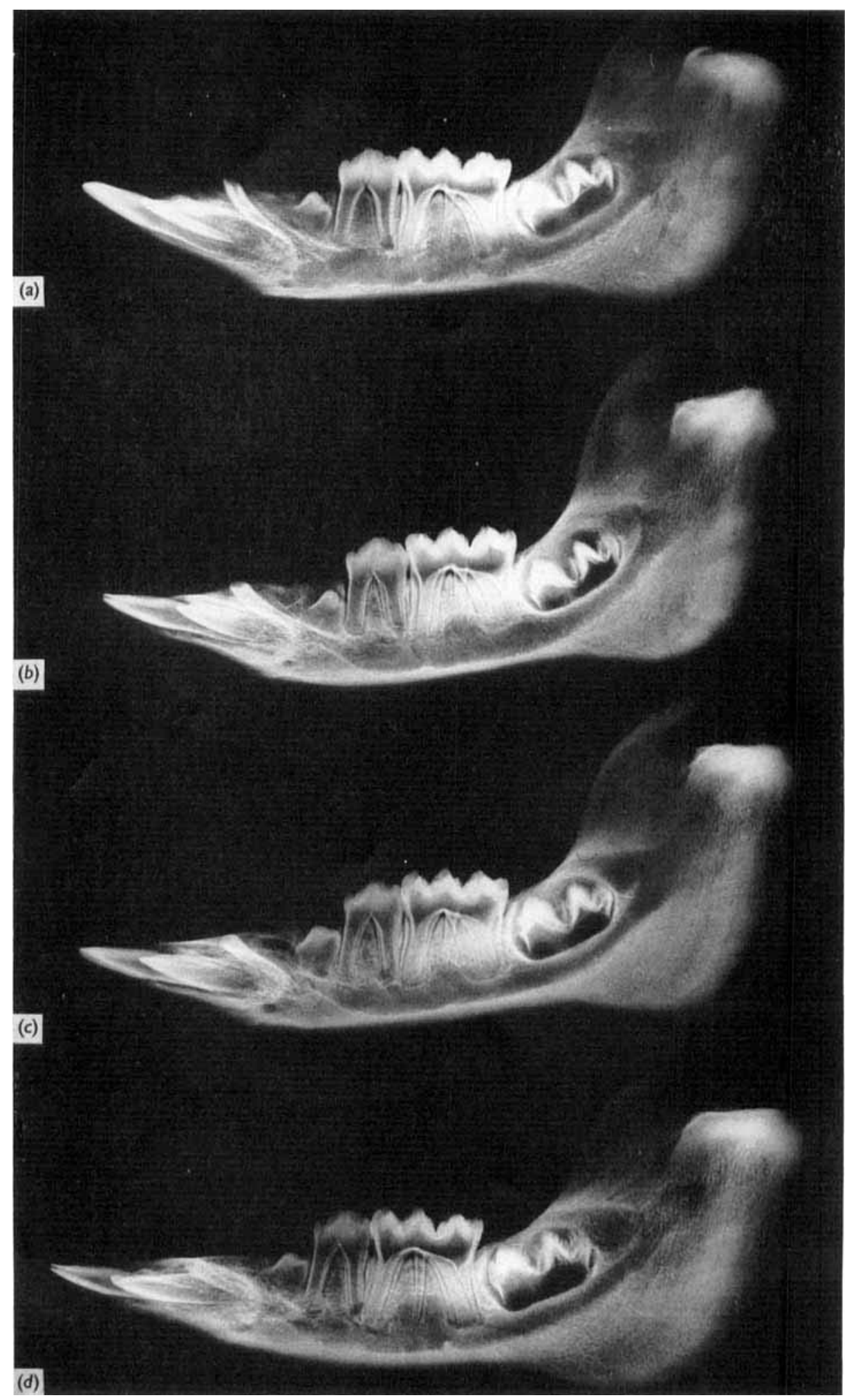

R. BLAIR AND D. BENZIE 


\section{CORRIGENDUM}

The effect of level of dietary calcium and phosphorus on skeletal development in the young pig up to $25 \mathrm{lb}$. live weight

BY R. BLAIR AND D. BENZIE

$$
\text { Vol. } 18 \text { (1964), No. I }
$$

Plate 1 (Facing p. I00): The images, but not the letters, have been reversed.

For $a$ read $d$; for $b \operatorname{read} c$; for $c \operatorname{read} b ;$ for $d$ read $a$. 
Combs, G. E., Vandepopuliere, J. M., Wallace, H. D. \& Koger, M. (1962). F. Anim. Sci. 2r, 2. Dudley, W. A., Becker, D. E., Norton, H. W. \& Jensen, A. H. (1961). F. Anim. Sci. 20, 93 r. Freese, H. H. (1958). Arch. Tierernähr. 8, 330.

Harris, H. A. (1933). Bone Growth in Health and Disease. London: Oxford University Press.

Hughes, E. H. \& Hart, H. G. (1935). F. Nutr. 9, 31 I.

Lengemann, F. W., Wasserman, R. H. \& Comar, C. L. (1959). Fed. Proc. 18, 533.

Livingstone, R. M., Lucas, I. A. M. \& McDonald, I. (1962). Anim. Prod. 4, 297.

Miller, E. R., Ullrey, D. E., Zutaut, C. L., Baltzer, B. V., Schmidt, D. A., Hoefer, J. A. \& Luecke, R. W. (1961). F. Anim. Sci. $20,944$.

National Research Council (1959). Publ, nat. Res. Coun., Wash., no. 648.

Perrin, D. R. (1955). Y. Dairy Res. 22, 103.

Rutledge, E. A. (1957). Diss. Abstr. $17,1855$.

Rutledge, E. A., Hanson, L. E. \& Meade, R. J. (196x). F. Anim. Sci. 20, 243.

Shanks, P. L. (1953). Vet. Rec. 65, 58.

Vandepopuliere, J. M., Combs, G. E., Wallace, H. D. \& Koger, M. (1959). Y. Anim. Sci. 18, I 505.

Weinmann, J. P. \& Sicher, H. (1955). Bone and Bones, 2nd ed. London: Henry Kimpton.

Zimmerman, D. R., Speer, V. C. \& Hays, V. W. (1961). F. Anim. Sci. $20,957$.

\section{EXPLANATION OF PLATES}

\section{Plate I}

Effect of level of dietary calcium and phosphorus on closure of the distal epiphysial cartilage (indicated by arrows) of the ulna of the young pig.

(a) $0.4 \% \mathrm{Ca}, 0.6 \% \mathrm{P}$ in diet. Mean width of cartilage $0.39 \mathrm{~cm}$.

(b) $0.8 \% \mathrm{Ca}, 0.9 \% \mathrm{P}$ in diet. Mean width of cartilage $0.34 \mathrm{~cm}$.

(c) $\mathrm{I} \cdot 2 \% \mathrm{Ca}, \mathrm{x} \cdot 2 \% \mathrm{P}$ in diet. Mean width of cartilage $0.30 \mathrm{~cm}$.

(d) $\mathrm{I} \cdot 6 \% \mathrm{Ca}, \mathrm{I} \cdot 5 \% \mathrm{P}$ in diet. Mean width of cartilage $0.23 \mathrm{~cm}$.

\section{Plate 2}

Effect of level of dietary calcium and phosphorus on radiographic density (\%) of the mandible of the young pig

(a) $0.4 \% \mathrm{Ca}, 0.6 \% \mathrm{P}$ in diet. Mean radiographic density 24.6 .

(b) $0.8 \% \mathrm{Ca}, 0.9 \% \mathrm{P}$ in diet. Mean radiographic density 26.6 .

(c) $1 \cdot 2 \% \mathrm{Ca}, \mathrm{1} \cdot 2 \% \mathrm{P}$ in diet. Mean radiographic density 30.0 .

(d) $\mathrm{r} .6 \% \mathrm{Ca}, \mathrm{x} \cdot 5 \% \mathrm{P}$ in diet. Mean radiographic density 34.2 . 